\title{
PENGARUH PENERAPAN MODEL ELICITING ACTIVITIES TERHADAP PRESTASI BELAJAR MATEMATIKA SISWA KELAS VIII SMP
}

\author{
Made Juniantari \\ Program Studi Pendidikan Matematika, Universitas Pendidikan Ganesha \\ Email: mdjuniantari@undiksha.ac.id \\ I Nyoman Sukajaya \\ Program Studi Pendidikan Matematika, Universitas Pendidikan Ganesha \\ Email: nyoman.sukajaya@undiksha.ac.id \\ Luh Putu Eka Ratna Wulandari \\ Program Studi Pendidikan Matematika, Universitas Pendidikan Ganesha \\ Email: ekaratna19@gmail.com
}

\begin{abstract}
Abstrak
Penelitian ini bertujuan untuk mengetahui apakah prestasi belajar matematika siswa yang dibelajarkan dengan model eliciting activities lebih tinggi daripada prestasi belajar matematika yang dibelajarkan dengan pembelajaran konvensional. Populasi dalam penelitian ini adalah siswa kelas VIII Non Unggulan SMP Negeri 1 Singaraja pada semester II tahun ajaran 2017/2018 yang tersebar ke dalam 7 kelas. Sampel penelitian ditentukan dengan teknik cluster random sampling. Peneliti telah menguji kesetaraan populasi dan diperoleh hasil bahwa populasi memiliki kemampuan yang setara. Berikutnya diambil dua kelas yang dijadikan sampel. Kedua kelas tersebut diundi untuk menentukan kelas eksperimen dan kelas kontrol. Pengundian menghasilkan kelas VIII A6 sebagai kelas eksperimen dan kelas VIII A4 sebagai kelas kontrol. Penelitian ini dikategorikan penelitian eksperimen semu dengan desain penelitian post-test only control group design. Data tentang prestasi belajar matematika siswa dikumpulkan dengan menggunakan tes prestasi belajar. Data dianalisis dengan menggunakan uji-t satu ekor (ekor kanan) pada taraf signifikansi 5\%. Hasil analisis menunjukkan bahwa $t_{\text {hitung }}=1.31$ sedangkan dengan taraf signifikansi $5 \%$ diperoleh $t_{\text {tabel }}=0,063$. Nilai statistik ini memiliki makna bahwa prestasi belajar matematika siswa yang dibelajarkan dengan model eliciting activities lebih tinggi dibandingkan dengan prestasi belajar matematika siswa yang dibelajarkan dengan pembelajaran konvensional. Dengan kata lain terdapat pengaruh positif model eliciting activities terhadap prestasi belajar matematika siswa.
\end{abstract}

Kata kunci: model eliciting activities, pembelajaran konvensional, prestasi belajar matematika siswa

\begin{abstract}
This research aimed to determine whether the students' achievement of mathematics learning which were taught with eliciting activities model was higher than the students' achievement of mathematics learning that were taught by conventional learning. The population in this research was the students of SMP Negeri 1 Singaraja from the Non Excellent classes in the second semester of academic year 2017/2018 which was divided into 7 classes. The sample of this research was determined by cluster random sampling technique. Researchers had tested the equality of the population and then obtained that the population had equal ability. Afterwards, two classes were taken as samples. Those two classes were drawn to determine the experimental class and the control class. The draw obtained that VIII A6 class would be the experimental class and VIII A4 class would be control class. This research categorized as quasi experiment research with post-test design only control group design. The data about students' achievement of mathematics learning were collected using students' achievement learning test. Furthermore, the data were analyzed by t-test one tail (right tail) at 5\% significance level. The result of analysis showed that $t_{\text {count }}=1.31$ whereas with significance level $5 \%$ obtained $t_{\text {table }}=0,063$. This statistic score mean that the students' achievement of mathematics learning who were taught with eliciting activities model was higher than the students' achievement of mathematics learning who taught by conventional learning. So there was a positive effect of eliciting activities model on students' achievement of mathematics learning.
\end{abstract}

Keywords: eliciting activities model, conventional learning, students achievement of mathematics learning 


\section{Pendahuluan}

Dalam suatu lembaga pendidikan keberhasilan proses belajar mengajar dapat dilihat dari prestasi belajar yang dicapai oleh siswa. Menurut Hamdani (2011:138) prestasi belajar adalah hasil yang diperoleh berupa kesan-kesan yang mengakibatkan perubahan dalam diri individu sebagai hasil dan aktivitas dalam belajar. Sejalan dengan itu, Syah (2008:91) mengatakan bahwa prestasi belajar adalah taraf keberhasilan siswa dalam mempelajari materi pelajaran di sekolah yang dinyatakan dalam bentuk skor yang diperoleh dari hasil tes mengenai sejumlah materi pelajaran tertentu. Secara umum dapat disimpulkan bahwa prestasi belajar adalah hasil yang dicapai oleh siswa setelah mengalami suatu proses belajar di sekolah dalam jangka waktu tertentu.

Sekolah sebagai pihak pengelola pendidikan telah melakukan berbagai usaha dalam rangka meningkatkan prestasi belajar siswa. Usaha yang telah dilakukan sekolah diantaranya melakukan perubahan-perubahan dalam pengorganisasian kelas, penggunaan model, metode, dan strategi belajar mengajar, serta menciptakan kondisi proses pembelajaran yang efektif. Dalam hal ini, diperlukan guru kreatif yang dapat membuat pembelajaran menjadi lebih menarik dan disukai oleh siswa. Suasana kelas perlu direncanakan dan dibangun sedemikian rupa agar siswa dapat memperoleh kesempatan untuk berinteraksi satu sama lain sehingga dapat diperoleh prestasi belajar yang maksimal.

Namun kenyataannya pendidikan formal di sekolah belum mampu menggiring siswa untuk mencapai prestasi belajar yang maksimal, hal ini terlihat dari penilaian oleh lembaga survey dunia salah satunya adalah PISA. Program for International Student Assesment (PISA) di bawah naungan Organization Economic Cooperation and Development (OECD) mengadakan survei tentang kemampuan siswa dan sistem pendidikan yang ada. Hasil survei terakhir yang dilakukan PISA tahun 2015 lalu dan baru dirilis di tanggal 6 Desember 2016 menyatakan bahwa kemampuan matematika siswa di Indonesia menduduki peringkat 69 dari 76 negara dengan skor 386. Dari survei tersebut terlihat bagaimana daya saing pendidikan Indonesia masih rendah jika dibandingkan dengan negara-negara di dunia. Selain itu, rendahnya prestasi belajar matematika siswa juga tercemin pada rata-rata nilai Ujian Nasional Matematika. Rata-rata nilai Ujian Nasional Matematika siswa SMP Se-Bali mengalami penurunan sebesar 2,92 dari tahun sebelumnya. Perubahan terjadi dari 46,55 pada tahun 2016 menjadi 43,63 pada tahun 2017. Hal ini menunjukkan bahwa kemampuan matematika siswa masih tergolong rendah yang mengindikasikan prestasi belajar matematika siswa juga rendah.

Rendahnya prestasi belajar matematika siswa menandakan bahwa ada sesuatu yang kurang tepat dan belum optimal dalam pembelajaran matematika di sekolah. Terdapat banyak faktor yang mempengaruhi prestasi belajar siswa, salah satu diantaranya minat belajar siswa (Slameto, 2003). Minat adalah suatu keadaan di mana seseorang mempunyai perhatian terhadap sesuatu dan disertai keinginan untuk mengetahui dan mempelajari maupun membuktikan (Walgito, 1981:38). Minat mempunyai hubungan yang erat dengan dorongan dalam diri individu yang kemudian menimbulkan keinginan untuk berpartisipasi atau terlibat pada sesuatu yang diminatinya. Minat belajar sangat penting dalam menunjang keberhasilan belajar dan berpengaruh pada prestasi belajar siswa. Hal ini sejalan dengan hasil penelitian Erlando Doni Sirait (2016) yang berjudul Pengaruh Minat Belajar Terhadap Prestasi Belajar Matematika. Penelitian ini menyimpulkan bahwa terdapat hubungan yang signifikan antara minat belajar terhadap prestasi belajar matematika dengan persamaan regresi $Y=22,15+$ 0,78x. Persamaan tersebut mengindikasikan bahwa semakin tinggi minat belajar seseorang maka semakin tinggi prestasi belajar matematikanya.

Selain itu, aspek-aspek pembelajaran matematika mencakup pembelajaran dan pemikiran yang kreatif. Berbagai permasalahan dalam kegiatan belajar mengajar sering dialami guru di sekolah. Permasalahan yang dialami tersebut tidak hanya bersumber pada kemampuan siswa yang kurang serta minatnya yang rendah, tetapi ada faktor lain yang ikut menentukan keberhasilan siswa dalam belajar matematika, salah satu diantaranya adalah model pembelajaran yang dipilih oleh guru sebagai pengajar (Slameto, 2003). Model pembelajaran merupakan kerangka konseptual yang menggambarkan prosedur sistematis dalam mengorganisasikan pengalaman belajar untuk mencapai tujuan tertentu serta berfungsi sebagai pedoman dalam merencanakan dan melaksanakan pembelajaran (Sudiarta, 2010). Pemilihan model pembelajaran harus dilakukan secara cermat. Salah satu model pembelajaran yang dapat diterapkan untuk meningkatkan prestasi belajar siswa adalah model pembelajaran eliciting activities. Model ini memaksimalkan kemampuan siswa dalam membangun suatu model matematika dari suatu permasalahan. Permasalahan yang diberikan merupakan permasalahan bersifat realistik/kontekstual dengan tujuan untuk meningkatkan minat serta penguasaan konsep matematika siswa yang mendorong pada peningkatan prestasi belajar matematika siswa.

Model eliciting activities terbentuk pada pertengahan tahun 1970-an untuk memenuhi kebutuhan pengguna kurikulum. Menurut Lesh et al. (dalam David Yun Dai, 2012), model ini disusun oleh para pendidik, profesor dan lulusan di seluruh Amerika dan Australia. Model eliciting activities adalah model pembelajaran matematika untuk memahami, menjelaskan, dan mengkomunikasikan konsep-konsep matematika yang terkandung dalam suatu sajian permasalahan melalui pemodelan matematika. Jadi, siswa tidak hanya sekedar menghasilkan model matematika tetapi juga mengerti konsep-konsep yang digunakan dalam pembuatan model matematika dari permasalahan yang diberikan. Ciri khas pembelajaran model eliciting activities dilakukan dengan memberikan permasalahan yang bersifat realistik/ kontekstual, tujuannya untuk meningkatkan ketertarikan siswa dalam menyelesaikan suatu persoalan. Dengan mengaitkan pembelajaran pada situasi dunia nyata siswa, konsep-konsep yang bersifat abstrak dapat dijelaskan dengan baik dan siswa akan termotivasi untuk lebih aktif dalam mengikuti pembelajaran. Selain itu juga permasalahan yang diberikan dengan masalah nyata memberikan dampak positif terhadap penguasaan konsep dan minat siswa, serta mendorong terjadinya perubahan belajar dari menghafal rumus menjadi belajar bermakna dan menerapkannya dalam kehidupan sehari-hari.

Kelebihan model ini yaitu siswa dihadapkan permasalahan dalam kehidupan nyata (the reality principle), siswa dilatih membangun model matematika sendiri untuk menyelesaikan permasalahan yang ada (the construction principle), siswa dilatih untuk mengembangkan kreatifitasnya, berpikir logis, dan kritis, serta siswa dilatih bekerja sama dengan anggota kelompoknya. Model eliciting activities disusun untuk membantu siswa membangun pemecahan masalah dunia nyata ke arah konstruksi matematis dan terbentuk karena adanya kebutuhan untuk membuat siswa menerapkan prosedur matematis yang telah dipelajari sehingga dapat membentuk model matematis. Model ini terdiri dari tujuh langkah yaitu : (1) mencermati masalah, (2) memberikan jawaban sementara atas permasalahan, (3) mendiskusikan solusi permasalahan, (4) 
menyempurnakan solusi permasalahan, (5) membuat penyelesaian matematis untuk pemecahan masalah, (6) menguji dan merevisi solusi permasalahan, (7) mempresentasikan solusi permasalahan (Chamberlin dan Moon, 2012).

Pada langkah pertama siswa diajak mencermati permasalahan. Kegiatan ini dapat menuntun siswa dalam memvisualisasikan situasi masalah. Pada langkah kedua siswa menganalisis masalah sehingga mampu mengenali atau mengetahui adanya konsep, fakta, atau istilah-istilah, dan sebagainya yang ada dalam permasalahan. Selanjutnya siswa akan memberikan jawaban sementara atas permasalahan sebagai langkah awal dalam menemukan solusi. Pada langkah ketiga mendiskusikan solusi permasalahan dapat melatih siswa bekerja sama dalam kelompok untuk merancang solusi permasalahan. Pada langkah keempat menyempurnakan solusi permasalahan yaitu dengan menuntun siswa dalam membuat model matematika dari permasalahan yang diberikan. Model matematika ini berguna dalam menyederhanakan permasalahan sehingga dapat dengan mudah menemukan solusi yang tepat. Pada langkah kelima membuat penyelesaian matematis untuk memecahkan masalah masalah dapat melatih ketepatan matematika siswa. Pada langkah keenam dan ketujuh menguji, dan merevisi solusi permasalahan serta mempresentasikannya menuntun siswa dalam mengevaluasi solusi permasalahan dan mempertanggungjawabkan solusi tersebut. Berdasarkan pemaparan tersebut, terlihat bahwa ketujuh langkah dalam model eliciting activities merupakan satu kesatuan langkah yang bila diterapkan dapat meningkatkan prestasi belajar matematika siswa.

Hasil penelitian pun menunjukkan hasil positif terhadap penerapan model eliciting activities dalam pembelajaran matematika diantaranya: Ni Luh Nilam Brahaneswari (2017) dalam penelitian yang berjudul Penerapan Model Eliciting Activities (MEAs) Sebagai Upaya Meningkatkan Pemahaman Konsep Matematika Siswa Kelas X 3 SMAN 2 Banjar menyimpulkan bahwa pembelajaran MEAs mampu meningkatkan pemahaman konsep matematika siswa. Penelitian lainnya dilakukan oleh Luh Putu Teta Lamdani Nusantari (2015) dengan judul Pengaruh Model Eliciting Activities (MEAs) Terhadap Kemampuan Pemecahan Masalah Matematika Siswa Kelas VII SMP Negeri 2 Singaraja menyimpulkan bahwa pembelajaran dengan model eliciting activities memiliki pengaruh yang signifikan terhadap kemampuan pemecahan masalah matematika siswa. Pemahaman konsep dan kemampuan pemecahan masalah matematika siswa tidak terlepas dari prestasi belajar matematika siswa dimana kedua hal ini saling terkait satu sama lain karena jika siswa telah memiliki prestasi belajar matematika dengan baik maka ada kecenderungan pemahaman konsep dan kemampuan pemecahan masalah matematika yang dimiliki siswa baik. Oleh karena itu, diduga bahwa model eliciting activities berpengaruh terhadap prestasi belajar matematika siswa.

Berdasarkan uraian tersebut, dapat dirumuskan permasalahan yang menjadi bahan kajian dalam penelitian ini sebagai berikut apakah prestasi belajar matematika siswa yang mengikuti model eliciting activities lebih tinggi daripada prestasi belajar matematika siswa yang mengikuti pembelajaran konvensional. Penelitian ini memiliki tujuan untuk mengetahui apakah prestasi belajar matematika siswa yang dibelajarkan dengan menggunakan model eliciting activities lebih tinggi daripada siswa yang dibelajarkan menggunakan pembelajaran konvensional.

\section{Metode}

Penelitian ini merupakan penelitian Jenis penelitian ini adalah penelitian eksperimen, dalam kategori penelitian eksperimen semu (quasi experiment). Penelitian eksperimen semu dapat dilakukan untuk melihat pengaruh yang ditimbulkan dari perlakuan berbeda yang diberikan pada masing-masing kelompok, yang mana peneliti tidak mengontrol semua variabel dan kondisi eksperimen secara ketat (Sugiyono, 2012: 114). Desain penelitian yang digunakan adalah "Post test only control group design". Desain penelitian ini dapat dilihat padaTabel 1 berikut.

Tabel 1. Desain Penelitian

\begin{tabular}{ccc}
\hline Kelompok & Perlakuan & Post Test \\
\hline Eksperimen & $X_{1}$ & $Y_{1}$ \\
Kontrol & $X_{2}$ & $Y_{2}$
\end{tabular}

(Sugiyono, 2012)

Keterangan :

$X_{1}$ : Perlakuan dengan menerapkan pendekatan flipped classroom

$X_{2}$ : Perlakuan dengan menerapkan pembelajaran konvensional

$Y_{1}:$ Hasil post test kelompok eksperimen

$Y_{2}:$ Hasil post test kelompok kontrol

Populasi dalam penelitian ini adalah siswa kelas VIII non unggulan SMP Negeri 1 Singaraja yang terdiri dari 7 kelas dengan total 209 siswa. Teknik pengambilan sampel dalam penelitian ini menggunakan teknik cluster random sampling. Sebelum dilakukan pengambilan sampel, peneliti menguji kesetaraan populasi dengan menganalisis nilai ulangan umum semester ganjil siswa menggunakan rumus ANAVA Satu jalur. Berdasarkan hasil analisis diperoleh bahwa tidak terdapat perbedaan kemampuan awal siswa kelas VIII Non Unggulan SMP Negeri 1 Singaraja atau dapat dikatakan bahwa populasi memiliki kemampuan yang setara. Selanjutnya kedua kelas tersebut diundi untuk menentukan kelas eksperimen dan kelas kontrol. Hasil pengundian adalah sebagai berikut: (1) Kelas VIII A6 SMP Negeri 1 Singaraja sebagai kelompok eksperimen memperoleh perlakuan berupa pembelajaran dengan model eliciting activities, dan (2) Kelas VIII A4 SMP Negeri 1 Singaraja sebagai kelompok kontrol memperoleh perlakukan berupa pembelajaran dengan model konvensional yang dalam penelitian ini pembelajaran konvensional yang dimaksud adalah model pembelajaran kooperatif.

Penelitian ini melibatkan variabel bebas dan variabel terikat. Variabel bebas dalam penelitian ini adalah model eliciting activities. Adapun variabel terikat dalam penelitian ini adalah prestasi belajar matematika siswa. Instrumen penelitian adalah alat yang digunakan oleh peneliti untuk mengumpulkan data atau informasi yang relevan dengan permasalahan penelitian" (Rully dan Poppy, 2014: 112). Jenis instrumen yang digunakan dalam penelitian ini berupa tes. Data yang akan dikumpulkan pada penelitian ini adalah berupa prestasi belajar matematika siswa, yang dikumpulkan melalui 
tes tertulis berupa tes objektif. Tes objektif dipergunakan karena dapat mengukur pengetahuan yang luas dengan banyak testee yang bervariasi. Item tes objektif memiliki semua persyaratan sebagai tes yang baik, yakni dilihat dari segi objektifitas, reliabilitas, dan daya pembeda, dan tingkat kesukaran. Setelah siswa diberikan tes prestasi belajar matematika berbentuk tes objektif selanjutnya dilakukan pengujian hipotesis yang diajukan. Terlebih dahulu, data yang diperoleh dilakukan uji prasyarat yakni uji normalitas menggunakan uji Liliefors dan uji homogenitas varians menggunakan uji-F. Pengujian hipotesis dilakukan dengan menggunakn uji-t satu ekor (ekor kanan). Adapun rumus uji-t dengan taraf signifikansi 5\% adalah sebabagi berikut:

dengan

$$
t_{\text {hitung }}=\frac{\overline{Y_{1}}-\overline{Y_{2}}}{\sqrt{\frac{s^{2}}{n_{1}}+\frac{s^{2}}{n_{2}}}}
$$

Keterangan :

$$
s^{2}=\frac{\left(n_{1}-1\right) s_{1}^{2}+\left(n_{2}-1\right) s_{2}^{2}}{\left(n_{1}+n_{2}-2\right)}
$$

$\overline{Y_{1}}:$ rata-rata skor dari kelompok eksperimen

$\overline{Y_{2}}$ : rata-rata skor dari kelompok kontrol

$s$ : simpangan baku gabungan

$s_{1}$ : simpangan baku dari kelompok eksperimen

$s_{2}$ : simpangan baku dari kelompok kontrol

$n_{1}$ : banyak subjek dari kelompok eksperimen

$n_{2}$ : banyak subjek dari kelompok kontrol

Kriteria pengujian adalah tolak $H_{0}$ jika $t_{\text {hit }} \geq t_{(1-\alpha)}$, dimana $t_{(1-\alpha)}$ didapat dari tabel distribusi $t$ pada taraf signifikasi $\alpha=5 \%$ dengan derajat kebebasan $(\mathrm{dk})=\left(n_{1}+n_{2}-2\right)$.

\section{Hasil dan Pembahasan}

Penelitian ini dilaksanakan di SMP Negeri 1 Singaraja yang meliputi delapan kali proses pembelajaran dan satu kali pertemuan untuk pelaksanaan post test. Penelitian ini melibatkan 59 orang siswa sebagai sampel yang terdistribusi ke dalam dua kelas yaitu kelas VIII A4 sebagai kelompok kontrol dan VIII A6 sebagai kelompok eksperimen. Data skor prestasi belajar matematika diperoleh dari hasil post test kelompok eksperimen dan kelompok kontrol. Rangkuman mengenai data prestasi belajar matematika siswa pada kedua kelompok disajikan pada Tabel 2 berikut.

Tabel 2. Rangkuman Data Prestasi Belajar Matematika Siswa

\begin{tabular}{lcc}
\hline \multirow{2}{*}{ Variabel } & \multicolumn{3}{c}{ Kelompok } \\
\cline { 2 - 3 } & Eksperimen & Kontrol \\
\hline Banyak Siswa $(\mathrm{N})$ & 29 & 30 \\
\hline Rata-rata $(\bar{Y})$ & 18 & 16,73 \\
\hline Standar Deviasi $(\mathrm{S})$ & 3,75 & 3,64 \\
\hline
\end{tabular}

Berdasarkan Tabel 2 terlihat adanya perbedaan antara kelompok kontrol dan kelompok eksperimen. Rata-rata skor prestasi belajar matematika siswa kelas eksperimen lebih tinggi dibandingkan dengan prestasi belajar matematika kelas kontrol. Sebelum melakukan pengujian hipotesis terlebih dahulu dilakukan uji prasyarat analisis yaitu uji normalitas dan uji homogenitas. Rangkuman hasil uji normalitas kelas eksperimen dan kontrol dapat dilihat pada Tabel 3 berikut.

\begin{tabular}{|c|c|c|c|c|}
\hline No & Kelompok & $\mathrm{L}_{\text {hitung }}$ & $\mathrm{L}_{\text {tabel }}$ & Keterangan \\
\hline 1 & Eksperimen & 0,098 & \multirow{2}{*}{0,161} & Normal \\
\hline 2 & Kontrol & 0,146 & & Normal \\
\hline
\end{tabular}

Tabel 3. Rangkuman Hasil Uji Normalitas Skor Prestasi Belajar

Berdasarkan Tabel 3 dapat dilihat bahwa $\mathrm{L}_{\text {hitung }}$ kedua kelompok lebih kecil dari $\mathrm{L}_{\text {tabel }}$ pada kelas yang bersangkutan. Dengan demikian $\mathrm{H}_{0}$ diterima dan hal tersebut berarti bahwa masing-masing kelas memiliki skor tes prestasi belajar matematika yang berdistribusi normal. Setelah menguji normalitas data kemudian akan diuji homogenitas terhadap varians pasangan antar kelompok eksperimen dan kontrol. Uji yang digunakan adalah uji-F dengan kriteria data homogen jika $F_{\text {hitung }}<\mathrm{F}_{\text {tabel. }}$. Rangkuman hasil uji homogenitas varians antar kelompok eksperimen dan kontrol disajikan pada Tabel 4 berikut.

\begin{tabular}{|c|c|c|c|c|c|}
\hline No & Kelompok & Varians & $\mathrm{F}_{\text {hitung }}$ & $\mathrm{F}_{\text {tabel }}$ & Keterangan \\
\hline 1 & Eksperimen & 13,513 & \multirow{2}{*}{1,041} & \multirow{2}{*}{1,875} & \multirow{2}{*}{ Homogen } \\
\hline 2 & Kontrol & 14,071 & & & \\
\hline
\end{tabular}

Tabel 4. Rangkuman Hasil Uji Homogenitas Skor Prestasi Belajar

Berdasarkan Tabel 4 dapat dilihat bahwa $\mathrm{F}_{\text {hitung }}<\mathrm{F}_{\text {tabel }}$, sehingga $\mathrm{H}_{0}$ diterima. Hal ini berarti skor tes prestasi belajar matematika siswa di kelas eksperimen dan kelas kontrol memiliki varians data homogen. Berdasarkan hasil uji prasyarat yang telah dilakukan, diperoleh hasil bahwa skor prestasi belajar matematika siswa berdistribusi normal dan memiliki varians yang homogen sehingga pengujian hipotesis penelitian dapat dilakukan. Pengujian hipotesis dilakukan dengan menggunakan 
uji- $t$ satu ekor (ekor kanan) dengan taraf signifikansi 5\%. Adapun rangkuman hasil pengujian hipotesis penelitian disajikan pada Tabel 5 berikut.

Tabel 5. Ringkasan Hasil Analisis Uji- $t$

\begin{tabular}{cccccc}
\hline No & Kelompok & $\mathrm{N}$ & $\mathrm{Dk}$ & $t_{\text {hitung }}$ & $t_{\text {tabel }}$ \\
\hline 1 & Eksperimen & 29 & \multirow{2}{*}{57} & \multirow{2}{*}{1,3095} & \multirow{2}{*}{0,0630} \\
\hline 2 & Kontrol & 30 & & & \\
\hline
\end{tabular}

Berdasarkan Tabel 5 diperoleh nilai $t_{\text {hitung }}=1,3095$. Oleh karena nilai $t_{\text {hitung }}$ lebih dari nilai $t_{\text {tabel }}$ maka $\mathrm{H}_{0}$ ditolak. Artinya pada taraf signifikansi 5\%, prestasi belajar matematika siswa kelas VIII SMP Negeri 1 Singaraja yang mengikuti pembelajaran matematika dengan model eliciting activities lebih lebih tinggi dari skor prestasi belajar matematika siswa yang mengikuti pembelajaran matematika konvensional.

Hasil analisis terhadap skor prestasi belajar matematika siswa terhadap siswa kelas eksperimen dan kontrol menunjukkan bahwa rata-rata skor prestasi belajar matematika siswa pada kelompok eksperimen lebih tinggi daripada skor prestasi belajar matematika siswa kelompok kontrol. Hal ini dikarenakan model eliciting activities mampu mengoptimalkan partisipasi siswa dalam proses pembelajaran. Selain itu, model eliciting activities juga memberikan kesempatan kepada siswa untuk menemukan konsep sendiri sehingga konsep yang dipelajari dapat bertahan lama. Salah satu penyebab adanya perbedaan rata-rata skor prestasi belajar matematika siswa pada kelompok eksperimen dan kelompok kontrol adalah perbedaan perlakuan antara kelompok eksperimen dan kelompok kontrol. Perlakuan yang dimaksud adalah adanya perbedaan kegiatan pembelajaran yang berlangsung di kelas. Perbedaan tersebut dapat dilihat pada langkah-langkah pembelajaran yang dilaksanakan.

Pembelajaran model eliciting activities diawali dengan adanya permasalahan kontekstual/realistik sesuai dengan materi terkait. Siswa diberikan kesempatan untuk mencermati permasalahan tersebut pada LKS yang telah diberikan. Guru berkeliling membimbing siswa untuk mencermati permasalahan realistik/kontekstual yang diberikan serta memastikan bahwa siswa memahaminya. Kegiatan dilanjutkan dengan memberikan jawaban sementara atas permasalahan, siswa terlebih dahulu diarahkan untuk dapat mengumpulkan fakta-fakta atau data yang terdapat pada permasalahan. Jawaban sementara yang dibuat siswa dapat berupa bagan penyelesaian ataupun pemisalan yang dilakukan atas permasalahan. Setelah itu siswa mendiskusikan solusi permasalahan. Kegiatan ini melatih siswa untuk dapat bekerja sama dan saling bertukar pikiran dalam menentukan kemungkinan solusi yang digunakan dalam menyelesaikan permasalahan. Solusi yang telah didiskusikan oleh siswa bersama kelompoknya disempurnakan dengan jalan menghasilkan sebuah model matematika. Menghasilkan model matematika ini merupakan karakteristik dari model eliciting activities. Guru pada tahap ini dapat menekankan kembali konsep-konsep penting dari materi yang dikaji. Dari model matematika yang dihasilkan, siswa membuat solusi (melakukan perhitungan) matematis. Solusi yang telah didapat dievaluasi bersama anggota kelompok dan dipresentasikan di depan kelas. Guru menunjuk salah satu siswa sebagai perwakilan kelompok untuk mempresentasikan solusi yang didapat kelompoknya. Dalam hal ini guru berperan sebagai moderator yang memandu diskusi antar kelompok dan memberikan klarifikasi terhadap kesimpulan tersebut dengan tujuan agar diperoleh solusi yang tepat jika ada kesalahan.

Berbeda halnya dengan pembelajaran konvensional. Pada awal pembelajaran guru menyampaikan materi yang akan dipelajari kepada seluruh siswa. Guru membentuk siswa menjadi beberapa kelompok dengan anggota empat sampai lima orang. Setiap kelompok mendapatkan sebuah LKS yang dikerjakan secara berkelompok dengan waktu yang telah ditentukan. Setelah selesai mengerjakan LKS, siswa diberikan kesempatan untuk mempresentasikan hasil diskusi kelompoknya. Seluruh kegiatan ini memiliki beberapa kesamaan dengan kegiatan pada pembelajaran model eliciting activities, yang membedakannya yaitu adanya aktivitas memberikan jawaban sementara atas permasalahan, membuat model matematika dan melakukan evaluasi terhadap solusi yang diperoleh. Kegiatan siswa dalam diskusi pada pembelajaran konvensional hanya terbatas pada mengidentifikasi informasi yang diketahui dan ditanyakan selanjutnya pembahasan permasalahan.

Siswa yang mampu membuat jawaban sementara atas permasalahan lebih mengetahui tujuan dalam memperoleh solusi atas permasalahan dan selanjutnya mengetahui apa saja yang seharusnya diuji kebenarannya berdasarkan informasi yang telah diketahui. Sedangkan aktivitas membuat model matematika bermanfaat dalam menyederhanakan permasalahan sehingga solusi permasalahan dapat dengan mudah didapat serta adanya kejelasan mekanisme dalam memperoleh solusi permasalahan. Adanya tahap mengevaluasi solusi permasalahan berguna dalam melatih ketelitian siswa sehingga selalu memeriksa kembali pekerjaannya. Siswa yang mengikuti pembelajaran konvensional sering mengalami kesulitan dalam menentukan informasi mana yang perlu dan tidak perlu digunakan serta kesulitan dalam mengubah kalimat masalah seharihari menjadi kalimat matematika. Siswa juga sering mengalami kesulitan dalam memahami apa yang dicari pada soal yang diberikan. Hal ini yang menyebabkan siswa susah untuk mencari penyelesaian yang tepat serta sering keliru dalam menggunakan rumus yang berkaitan dengan permasalahan yang diberikan.

Secara umum, pelaksanaan pembelajaran dengan model pembelajaran eliciting activities dapat berjalan baik dan sesuai rencana. Walaupun demikian, dalam pelaksanaannya di kelas tidak luput dari adanya kendala-kendala. Adapun kendala-kendala yang dihadapi adalah (1) memerlukan manajemen waktu yang baik dalam persiapan maupun pelaksanaan proses pembelajaran dengan menggunakan dengan model pembelajaran eliciting activities. Hal ini disebabkan siswa yang membutuhkan waktu cukup lama untuk pembentukan konsep diri tentang suatu materi dan siswa biasanya ada yang tidak terbiasa bekerja kelompok. (2) Siswa sulit menuangkan idenya kedalam bentuk matematis karena masih belum terbiasa sehingga diperlukan trik untuk mengarahkan siswa agar mampu terbiasa dan terlatih menuliskan ide yang dimiliki untuk membuat perencanaan yang sistematis dalam menyelesaikan soal. (3) Pada saat fasilitator mempresentasikan hasil diskusi di depan kelas, siswa masih terlihat malu-malu untuk menyampaikan kepada siswa lain. Pada awal pertemuan hanya sedikit siswa yang berani mengemukakan pendapatnya. Beberapa diantaranya harus ditunjuk terlebih dahulu untuk mengungkapkan ide dan pendapatnya.

Namun kendala-kendala tersebut dapat ditangani dengan baik. Kendala-kendala tersebut dapat ditangani dengan membatasi waktu untuk masing-masing kegiatan agar tidak terjadi kekurangan waktu selama proses pembelajaran. Kemudian, pada setiap awal pertemuan guru harus mengingatkan kembali tahapan-tahapan pembelajaran yang harus 
dilakukan oleh siswa. Yang terakhir adalah dengan memberikan penghargaan berupa nilai tambahan kepada siswa dan kelompoknya yang berani mempresentasikan hasil diskusi di depan kelas, agar mereka memiliki semangat dan keberanian untuk mempresentasikan hasil diskusi.

Seluruh kegiatan yang dilakukan dalam model eliciting activities sudah mengurangi dominasi guru sehingga peran guru dapat sebagai fasilitator dan motivator membantu siswa yang mengalami kesulitan dalam pembelajaran serta menciptakan suasana kondusif bagi berlangsungnya pembelajaran. Pembelajaran dengan model eliciting activities dilaksanakan dengan diskusi kelompok guna melatih siswa untuk dapat bekerja sama dengan anggota kelompok diskusi. Melalui tahap pembuatan model matematika dari suatu permasalahan siswa dibentuk untuk memahami soal secara mendalam, memilah informasi yang penting untuk digunakan, dan siswa terbiasa untuk menyelesaikan permasalahan secara matematis. Adanya permasalahan kontekstual/realistik dapat mengembangkan kreatifitas, berpikir logis, dan kritis siswa. Dengan demikian, pembelajaran yang dilakukan oleh siswa dapat memberikan pengalaman sehingga siswa mampu untuk mengekspresikan, memahami, menginterpretasikan, dan mengevaluasi ide-ide matematika serta mampu menggunakan simbol atau istilah matematika.

Berdasarkan uraian tersebut, dapat dilihat bahwa model eliciting activities berpengaruh positif terhadap prestasi belajar matematika siswa. Hal ini ditunjukkan dengan hasil post-test siswa yang dibelajarkan dengan model eliciting activities memiliki rata-rata skor prestasi belajar matematika yang lebih tinggi daripada siswa yang dibelajarkan dengan pembelajaran konvensional.

\section{Simpulan}

Berdasarkan hasil pengujian hipotesis yang menggunakan uji- $t$ pada taraf signifikansi $5 \%$ diperoleh nilai $t_{\text {hitung }}=$ 1,3095 > $t_{\text {tabel }}=0,0630$ mengakibatkan menolak $\mathrm{H}_{0}$ yang berarti prestasi belajar matematika siswa yang dibelajarkan dengan model eliciting activities lebih tinggi daripada prestasi belajar matematika siswa yang dibelajarkan dengan model pembelajaran konvensional. Dengan demikian dapat disimpulkan bahwa model eliciting activities memberikan pengaruh positif terhadap prestasi belajar matematika siswa.

Berdasarkan hasil penelitian yang diperoleh, peneliti melalui tulisan ini mengajukan beberapa saran. Adapun saransaran yang dapat disampaikan yakni: 1) Kepada praktisi pendidikan, khususnya guru pelajaran matematika diharapkan dalam pembelajaran di kelas untuk menerapkan model eliciting activities sebagai salah satu alternatif pembelajaran mengingat pengaruh positif yang diberikan model ini terhadap prestasi belajar matematika siswa, 2) Bagi peneliti lain disarankan untuk mengujicobakan pengaruh model eliciting activities terhadap aspek pembelajaran yang berbeda misalkan pada motivasi belajar matematika siswa. Model eliciting activities memiliki beberapa kendala salah satunya siswa sulit menuangkan idenya kedalam bentuk matematis. Dalam melakukan penelitian menggunakan model pembelajaran eliciting activities diharapkan memperhatikan kendala tersebut sebagai bahan pertimbangan untuk perbaikan dan penyempurnaan pelaksanaan penelitian selanjutnya.

\section{Daftar Pustaka}

Hamdani, A. M. 2010. Strategi Belajar Mengajar. Bandung: CV Pustaka Setia.

Brahaneswari, N. L. N. 2017. Penerapan Model Eliciting Activities (MEAs) Sebagai Upaya Meningkatkan Pemahaman Konsep Matematika Siswa Kelas X 3 SMAN 2. Skripsi (Tidak Diterbitkan). Jurusan Pendidikan Matematika, UNDIKSHA Singaraja.

Candiasa, I M. 2010. Statistik Univariat dan Bivariat Disertai Aplikasi SPSS. Singaraja: Undiksha.

Chamberlin, M. 2004. "Design Principles for Teacher Investigations of Student Work",Mathematics Teachers Education and Development". Colorado: University of Northern Colorado, Volume 6 (hlm. 52-62).

Chamberlin, S. A. dan Moon, S. M. 2005. "Model-Eliciting Activities as a Tool to Delevop and Identify Creatively Gifted Mathematicians". Journal of Secondary Gifted Education, Vol. XVII, No.1, P.37,39,40,.Tersedia pada http://files.eric.ed.Gov/fulltext/EJ7 46044.pdf,. (diakses tanggal 4 Desember 2017).

Chamberlin, S. A. dan Moon, S. M. 2008. "How Does The Problem Based Learning Approach Compare to The ModelEliciting Activity in Mathematics?". Tersedia pada http://cimt.plymouth.ac.uk (diakses pada tanggal 4 Desember 2017).

Dai, D. Y. 2012. Design Research on Learning and Thinking in Educational Settings. Florence Production.

Hamilton, E., Lesh, R., \& Lester, F. 2008. "Model-Eliciting Activities (MEAs) as a Bridge Between Engineering Education Research and Mathematics Education Research. Advances in Engineering Education". Tersedia pada http://aaee.com.au/conferences/AA EE2009/PDF/AUTHOR/AE090130.PDF. (diakses tanggal 5 Desember 2017).

Nusantari, L. P. T. L. 2015. Pengaruh Model-Eliciting Activities (MEAs) Terhadap Kemampuan Pemecahan Masalah Matematika Siswa Kelas VII SMP Negeri 2 Singaraja. Skripsi (Tidak Diterbitkan). Jurusan Pendidikan Matematika, UNDIKSHA Singaraja.

Sirait, E. D. 2016. "Pengaruh Minat Belajar Terhadap Prestasi Belajar Matematika". Tersedia pada https://media.neliti.com/media/publications/ 234901-pengaruh-minat-belajar-terhadap-prestasi-c06f683c.pdf. (diakses pada tanggal 5 Desember 2017).

Slameto. (2003). Belajar dan Faktor-Faktor yang Mempengaruhinya. Jakarta: PT Rineka Cipta.

Sudiarta, P. and Putu, G., 2010. Pengembangan model pembelajaran inovatif. Karangasem: Makalah Pelatihan MGMP.

Sugiyono. 2012. Metode Penelitian Pendidikan. Bandung : Alfabeta.

Syah, M. 2008. Psikologi Belajar. Bandung: PT. Remaja Rosdakarya.

Walgito, B. 1981. Pengantar Psikologi Umum. Yogyakarta: Universitas Gajah Mada.

Yaniawati, P. Dan Indrawan, R. 2014. Metodelogi Penelitian. Bandung: Refika Aditama. 